IRSH 60 (20I 5), Special Issue, pp. I 2 I-I 43 doi: I0.10 I 7/So0208 590 I 5000437 (C) 2015 Internationaal Instituut voor Sociale Geschiedenis

\title{
The Uneven Recruitment of Korean Miners in Japan in the I9I0s and I920s: Employment Strategies of the Miike and Chikuhō Coalmining Companies
}

\author{
TOM ARENTS \\ Graduate School of Regional Management, \\ Sapporo Gakuin University \\ Bunkyōdai I I, Ebetsu-shi, 069-8555, Japan
}

E-mail: tom_arents@hotmail.com

\author{
NORIHIKO TSUNEISHI \\ Graduate School of Architecture, Planning and Preservation, \\ Columbia University \\ I I72 Amsterdam Avenue, NY I0027, New York, USA \\ E-mail: nt2296@columbia.edu
}

\begin{abstract}
After Japan's colonization of Korea in I910, many Korean peasants lost their land owing to the changes imposed in agriculture, and several Japanese coalmining companies started to recruit them as a colonial surplus population. Despite the low wages they offered, not all of the companies relied on Korean miners - the distribution of this workforce was strikingly uneven. Focusing on the mines of Chikuhō and Miike in the Fukuoka prefecture during the I9IOs and I920s, this article argues that the distribution of Koreans was a consequence of uneven capital accumulation among different mining companies. This unevenness reflected the differing wages and recruitment policies of these companies. Correlating earlier groups of cheap labourers, such as convict workers, to this history, we suggest some explanations as to why some mining companies brought Korean workers into the coal-production process as an immediately available, cheap, and disposable workforce, while others did not.
\end{abstract}

In the first half of the twentieth century, Korean migrants became a vital workforce for coal production in Japan. In the period of Japanese colonization of the Korean peninsula between I9 Io and the end of World War II, many Korean peasants lost their lands to a handful of rich landowners. According to Ken Kawashima, a historian of Korean immigration in Japan, they turned into a "colonial surplus population", i.e. an extensive pool of cheaply available workers created, directly and indirectly, by the 
Japanese colonization. ${ }^{\mathrm{I}}$ These impoverished Korean peasants were recruited as wage labourers to work in different coalmining sites across Japan's empire, from the Kyūshū and Hokkaidō islands to South Sakhalin, which occupied part of present-day Sakhalin (see Figure I).

While some of the existing scholarship on the history of Japan's coal production underplays, if not almost completely ignores, the role of Korean workers, ${ }^{2}$ other scholarship emphasizes the ways in which the colonial workforce was mobilized, racially discriminated against, and exploited as a cheap labour force by Japanese mining companies. ${ }^{3}$ While sympathizing with those scholars, the present article will further complicate this narrative by revealing how, since the annexation of the peninsula in I9I0, Korean workers were unevenly distributed across different mining companies. The use of Korean workers was thus not a generalized phenomenon.

The varying distribution of Korean workers during the first few decades of colonization is often ignored in existing scholarship. ${ }^{4}$ In the late I93os, when Japan intensified its war efforts, virtually all major Japanese mining companies began to rely on the colonial workforce as forced labourers to cover wartime labour shortages. Before the late i930s, however, Korean miners were unevenly distributed across different companies. This article will focus on this earlier period, raising the question of why, if Korean miners were indeed a cheap workforce, not all companies used them to maximize their profits. If, from the perspective of Marxian political economy, capital's driving force is to "absorb the greatest possible amount of surplus labour", why did not all companies follow this logic?s

In order to explain the problem of uneven distribution, we will focus on two coalmining regions in south-western Japan, the Miike and Chikuho regions in the Fukuoka prefecture, located on Kyūshū island. Both had been major coalmining regions since the mid-nineteenth century, and stayed so until the last pit at the Miike Mine closed in 1997. The Miike Mine was the largest coalmine in Japan. It was operated by Mitsui Kōzan, which was part of Mitsui Zaibatsu. ${ }^{6}$

I. Ken Kawashima, The Proletarian Gamble: Korean Workers in Interwar Japan (Durham, NC, 2009), pp. $25-28$.

2. For example, Mikio Sumiya, Nihon Sekitan Sangyō Bunseki [An Analysis of the Japanese Coal Industry] (Tokyo, 1968).

3. For example, Yasuto Takeuchi, Chōsa: Chōsenjin Kyōsei Rōdō I: Tankō-hen [Investigation: Forced Labour of Koreans I: Coalmine] (Tokyo, 2013).

4. William Donald Smith points out the uneven distribution in passing, but does not investigate this topic in detail. See his "Ethnicity, Class and Gender in the Mines: Korean Workers in Japan's Chikuhō Coal Field, I917-1945” (Ph.D. dissertation, University of Washington, I999), p. 76.

5. Karl Marx, Capital, I (London, 1990), p. 342.

6. The notion of zaibatsu indicates a business conglomerate that emerged in the late nineteenth century in Japan. Mitsui Zaibatsu was one of the largest of these conglomerates. Led by Douglas MacArthur (Supreme Commander for the Allied Powers) following the Second World War, all zaibatsu were dissolved in 1947 . 




Figure I. The major coalfields of the Japanese Empire in the I9Ios.

In the Chikuhō region, meanwhile, there were several mines of varying size, administrated by different companies. Among them were Mitsui Kōzan as well, next to Mitsubishi Kōgyō, a company owned by Mitsubishi Zaibatsu, and Asō 
Table I. Places of origin of miners in the Chikubo coalfield in 1928.

\begin{tabular}{lrr}
\hline Birthplace & Number & Percentage \\
\hline Japan & 28,280 & \\
Fukuoka & 5,973 & 44.4 \\
Kumamoto & 5,933 & 9.4 \\
Oita & 4,278 & 9.3 \\
Hiroshima & 3,337 & 6.7 \\
Ehime & 2,853 & 5.2 \\
Saga & 2,202 & 4.5 \\
Kagoshima & 1,494 & 3.5 \\
Nagasaki & 1,305 & 2.3 \\
Miyazaki & 1,317 & 2.1 \\
Shimane & 1,048 & 2.1 \\
Yamaguchi & 5,626 & 1.6 \\
Korea & 63,646 & 8.8 \\
TOTAL & & 100.0 \\
\hline
\end{tabular}

Source: Fukuoka Chihō Shokugyō Shōkai Jimukyoku [Fukuoka Employment Bureau], Chikuhō Tankō Rōdōsha Shusshinchi Shirabe [Survey of Home Prefectures/Country of Chikuhō Miners] (Fukuoka, I928), p. 6.

Shōten, a smaller company that had emerged from within Chikuhō itself. In the I9IOS and I920s the mines in this region employed a large pool of Korean miners, alongside Japanese miners, both from within and outside the Fukuoka prefecture. A survey in 1928 indicated that almost 9 per cent of the miners originated from Korea (Table $\mathrm{I}$ ). According to this survey, the majority of these Koreans were from the provinces of North and South Cholla and North and South Gyeongsang, where according to Kawashima "peasant immiseration was greatest [during the interwar period]"?

While many companies in Chikuhō, such as Mitsubishi Kōgyō and Asō Shōten, employed a large number of Korean workers as early as the late I 9 Ios, during World War I, Mitsui Kōzan did not rely on them at Miike in the I9Ios and I920s, nor at their mines in Chikuhō. This article argues that the uneven recruitment of Korean workers was a consequence of uneven capital accumulation among those companies, and was related to the availability of workforces and the wage level at their mines.

This research first examines what preconditions prevailed at Miike and Chikuho when the aforementioned companies began developing their respective mines in the late nineteenth century. Varying geographies, production processes, and workforces caused different historical trajectories. In the following section we will show that the labour force employed by Mitsui Kōzan at the Miike Mine consisted of immediately available, cheap, 
and disposable Japanese miners: convict workers, and later also female pit workers, who were deployed when the use of prisoners had become restricted. We will then demonstrate how profits made at the Miike Mine at the expense of these cheap workers financially fuelled Mitsui's other mines in the Chikuho region, offering the company the possibility of paying the employees at those mines relatively high wages. As wages were a decisive factor in recruiting as well as in retaining miners, Mitsui Kōzan was able to keep enough Japanese miners in Chikuhō under the company's rather discriminatory guiding precept of Seibyo-Shugi (which might be translated as "elite troop-ism").

Conditions at the Mitsubishi Kōgyō and Asō Shōten mines in Chikuhō around the time of Japan's annexation of Korea in I9 Io differed from those at the Mitsui Kōzan mines. Compared to Mitsui Kōzan, wages at their mines were lower, which also implies that these two companies must have been less successful in securing a stable workforce of Japanese miners. We suppose that, because of the lack of a stable Japanese workforce, the two companies turned to the vast pool of the Korean colonial surplus population, produced by Japan's colonialism, as an immediately available labour supply. In a peculiar way, the Korean workers conjured up the role that the convict and other, non-convict miners had played for Mitsui Kōzan at Miike a few decades earlier. Productivity and the use of labour differed in these companies and mining sites, depending on their own preconditions and corresponding capital accumulation. This is the history of economic unevenness at work within Japan's capitalism during the interwar period, seen through the lens of immediately available, cheap, and disposable workforces.

\section{PRECONDITIONS AT MIIKE AND CHIKUHŌ}

Located relatively close to each other in the Fukuoka prefecture, Miike and Chikuhō were two of Japan's major coalmining regions (see Figure 2). The history of coal production at both locales predated the Meiji Restoration, which replaced the Tokugawa shōgunate with the imperial state in I 868 . Administered by local clans during the Tokugawa era (I603-I 868 ), coal production at that time was still insignificant in both regions, relying on manual labour with insufficient machinery. For Miike and Chikuhō to become prominent for what they are known for in Japan - the production of coal - both regions needed to wait for large capital, machineries, and infrastructures to be introduced.

At Miike in I 873 the new Meiji state intervened in the mine to extract coal for export. The quality of the bituminous coal from the Miike Mine was high. Also, as the mine was located by the Ariake Sea at the border of the present Fukuoka and Kumamoto prefectures, it was relatively easy to transport coal to the nearby Ōmuta port. Thanks to this location and the 


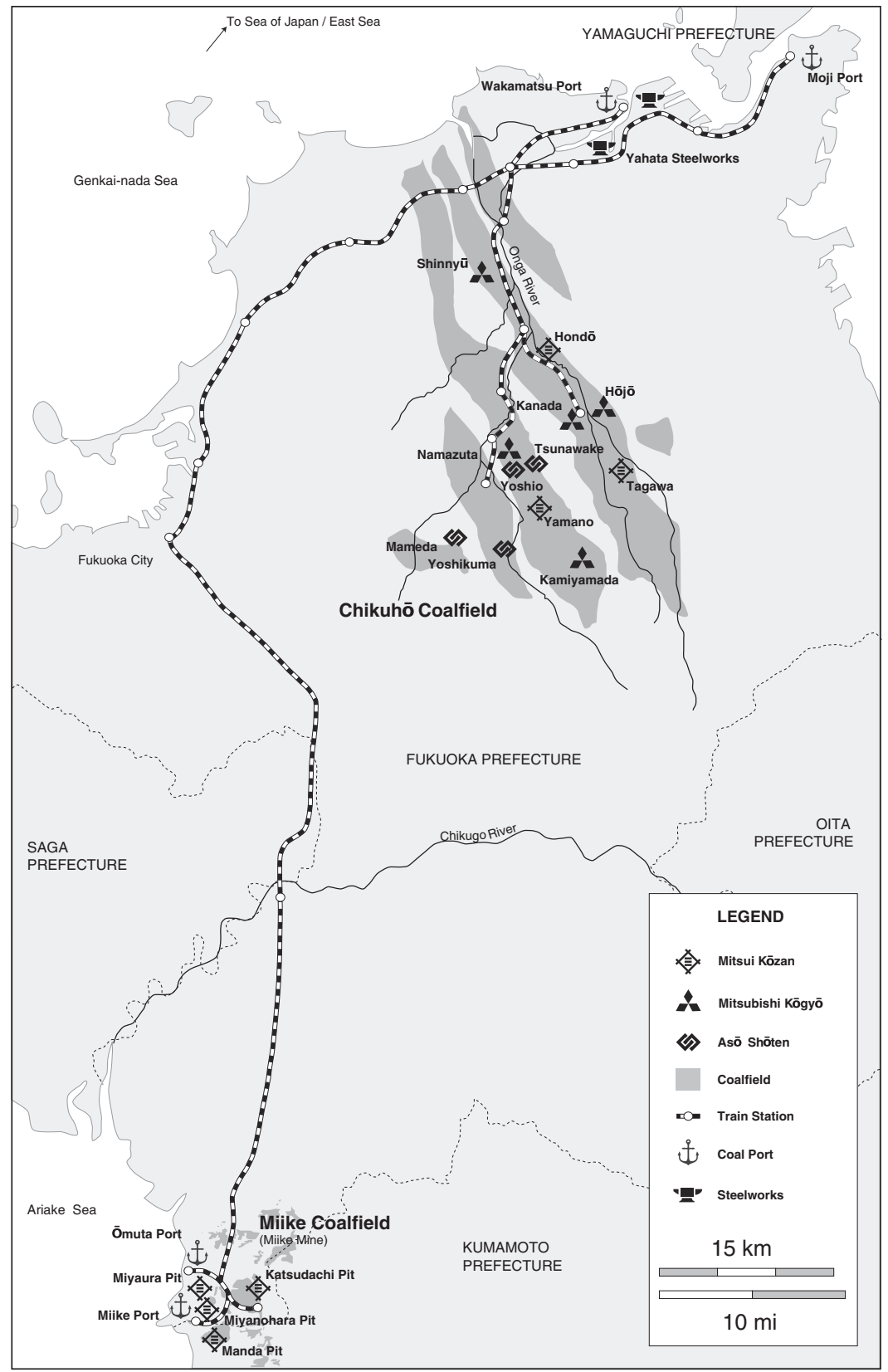

Figure 2. Mines and pits in the Miike and Chikuhō coalfields administrated by Mitsui Kōzan, Mitsubishi Kōgyō, and Asō Shōten. 
high quality of coal, the amount of coal exported from Miike increased from 409 tons in 1877 to 217,302 tons in $1888 .{ }^{8}$ Coal from the mine was sent to foreign trading ports, such as Hong Kong and Shanghai, by the Mitsui Bussan trading company, another key company owned by Mitsui Zaibatsu and which had been in charge of exports since the mid-I870s. As exports grew, the total output of coal further increased. Concomitantly, large amounts of capital were invested to mechanize the mining process, introducing, for instance, the steam-generated water pump. Financed and administrated by the state, the Miike Mine had the most advanced mechanical production process and by the late i 880 s it yielded the largest tonnage of coal of all Japan's mines.

In I888, with the profits gained through the trading business of Mitsui Bussan, Mitsui Zaibatsu won the bid over Mitsubishi Zaibatsu and purchased the Miike Mine from the state, taking over the operation fully the following year. After the takeover, Mitsui formally established the Mitsui Kōzan mining company in I 892. Since Mitsui Kōzan inherited all the existing infrastructure and workforce from the state, the company was able to jumpstart its operation. Included in the workforce were convict workers, as shown in the following section. The company further invested in new machinery (including the mechanical winch), the opening of new pits, and the construction of the Miike port in I908. As a result of these investments, the Miike Mine continued to be Japan's main coal-producing mine in terms of output.

In the Chikuho region, although located at a relatively short distance from Miike, the state was much less involved in the operation of mines after the Meiji Restoration in I 868. Mines previously owned by local clans during the Edo period became available for local merchants, allowing for the advent of endogenous mining companies. Without sufficient private capital of their own, these companies continued to rely on the primitive means of production carried over from the previous era. Their operations were far less industrialized than those of the state-owned Miike Mine. Devoid of large investments by the state, it took a longer time to develop the Chikuhō mines and to accumulate large capital.

The major obstacles in the region were the small size designated by the state to each mining concession and the large distance to the nearest port. The small concessions did not allow for a greater production of coal, and the transportation of coal to the port through the Onga river and its tributaries took a long time and thus was costly. These spatial and geographical circumstances were not attractive enough for the large companies to consider investing. These impediments began to dissolve only when the Sentei Kōku Sei [Coalmine District Reformation] was enacted by the state in I 888 to enlarge the minimum mining concession, and railway lines were 
constructed to connect the mines to the Moji port and Wakamatsu port, which were built around I 890 .

A few months after the enactment of the Sentei Kōku Sei, Mitsubishi Zaibatsu bought the Shinnyu Mine and Namazuta Mine, followed by the Kamiyamada Mine and Hōjō Mine in I 895. A few years later, Mitsui Kōzan also advanced into the region, purchasing the Yamano Mine in 1896 and the Tagawa Mine in 1900. ${ }^{9}$ Also, a handful of local companies, wealthy enough to increase their coal production, further expanded their operations. Asō Shōten was one of those endogenous companies, whose advent further industrialized the region. By 1895 , Chikuhō, together with Miike, was producing almost one-half of all coal extracted in Japan, fuelling the furnaces, for example, of the Yahata Steelworks (inaugurated near Chikuhō in present-day Kitakyūshū city in I90I).

Still, Chikuhō's growth was uneven. The larger companies, such as Mitsui Kōzan, were able to increase coal production quickly, while other companies with less capital had a different pace as well as size of production. Diverse conditions at the start of the industrialization of the mines allowed for the coexistence of multiple companies, big and small, jostling each other in the region. This economic unevenness among different companies in the region continued throughout the interwar period.

Along with geography and production, another major difference between the Miike and Chikuhō mines was the availability of labour. The mining process in both areas continued to rely heavily on human labour, regardless of the extent of mechanization at each mine. Procuring a guaranteed workforce in Chikuhō continued to trouble all companies, even during the interwar period when labourers seemed most readily available. The proximity of the mines in the region made it easy for the miners to leave one mine for another, and thus the retention of miners was a serious issue for the companies. In contrast, Mitsui Kōzan was able to overcome the difficulty of maintaining a stable workforce, at least at Miike, by employing convict workers, provided by the state. This enabled the company to accumulate more capital earlier and quicker than the other companies in Chikuhō. In addition, Mitsui Kōzan was virtually the only employer in Miike. Surrounded by farmlands with a surplus agrarian population, the mine was able to monopolize the supply of labour.

\section{CHEAP AND DISPOSABLE LABOUR AT MIIKE}

When the state began administrating the Miike Mine in 1873 , the majority of the workforce consisted of peasants who had been mining coal during the

9. Chikuhō Sekitan Kōgyō-shi Nenpyō Hensan Iinkai [Committee for the Compilation of a Historical Chronology of the Chikuhō Coal Industry] (ed.), Chikuhō Sekitan Kōgyō-shi Nenpyō [Historical Chronology of the Chikuhō Coal Industry] (Fukuoka, I973), pp. I68-i 80. 
off-season of their farm work. In order to increase coal production further, the state needed a more stable workforce and to that end it turned to prisoners.

As soon as the state began operations in 1873 , fifty prisoners were taken to the mine to transport coal to the nearby port. As far as the mining process was concerned, although the state introduced machinery into some of the major pits, the hauling and hewing of coal continued to rely on manual labour. Also, the underground water needed to be pumped out manually from the pits, as the steam-generated water pump was not widely available at that time. These jobs were not attractive, especially with the high temperature and humidity underground, making it even more difficult for the state-owned mine to find enough new miners. Hence, utilizing its juridical and prison apparatus, the state disciplined more prisoners to work in the mines to keep production going under these harsh conditions. Accordingly, the number of convict workers increased further in the following years.

Both the availability and the low cost of convict workers at the Miike Mine were crucial preconditions for Mitsui to continue mining after the takeover from the state. When the company purchased the mine in I 888 , it made sure it applied for permission to use convict workers. Although there are no exact figures, the wages for convict workers were roughly half those of non-convict miners. ${ }^{10}$ Based upon the low cost of the convict workers, Mitsui Kōzan was able to increase its profits. At its peak during the I 890 , convict workers constituted almost 70 per cent of the pit workforce. In this period, the company opened more pits and production at the mine drastically increased.

Every time a new pit was opened, and a new workforce was urgently needed, convict workers were relocated from the previous pit to work there for several years, until the company introduced new machinery, opened another pit, or hired non-convict workers. By using immediately available and cheap convict labour, Mitsui Kōzan was able to increase production further as well as to expand its capital. Simultaneously, convict workers were mobilized as a highly disposable workforce.

Two factors rendered convict workers no longer the "best option" at the Miike Mine. One was prison reform, the other was mechanization. In 1899 the state enacted the Prison Law (Kangoku Hō). As this law restricted the use of convict workers to a maximum of 400, Mitsui Kōzan needed to discharge many of them. This change of policy also reflected the impact of growing public criticism of the use of prisoners as

ı. Tetsuya Hashimoto, "Mitsui Kōzan to Shūjinnōdō” [Prison Labour at Miike Mine], Shakai Keizaigaku-shi [Social Economic History], 32 (I966), pp. 398-4I8, 403. 
Table 2. Number of workers at the Miike Mine, I894-I930.

\begin{tabular}{lccccr}
\hline & \multicolumn{2}{c}{ Pit workers } & & \multicolumn{2}{c}{ All workers } \\
\cline { 2 - 3 } Year & Convict & Non-convict & & Male & Female \\
\hline 1894 & 1,290 & 622 & 4,287 & 81 \\
1896 & 1,457 & 475 & 4,734 & 83 \\
1897 & 896 & 420 & 5,080 & 81 \\
1898 & 838 & 545 & & 4,936 & 79 \\
1899 & {$[$ n.a. } & {$[$ n.a. } & & 5,077 & 75 \\
1900 & {$[$ n.a. } & {$[$ n.a. } & & 4,520 & 572 \\
1901 & {$[$ n.a. } & 1,209 & 5,205 & 681 \\
1902 & 276 & 1,229 & 6,018 & 871 \\
1903 & 266 & 2,000 & 6,235 & 1,139 \\
1908 & 148 & 4,052 & 8,352 & 1,971 \\
1913 & 180 & 4,143 & 11,740 & 3,041 \\
1918 & 121 & 2,658 & 12,310 & 3,335 \\
1923 & 100 & 2,224 & 12,147 & 2,694 \\
1928 & 115 & 1,711 & 9,807 & 1,329 \\
1930 & 99 & 9,392 & 530 \\
\hline
\end{tabular}

Source: Mitsui Kōzan, Gojūnen-shi Kō, Iohen, Rōmu [Draft of 50 -Year History of Mitsui Kōzan, X, Labour Management] (Tokyo, I943). ${ }^{\text {I }}$

forced labour. ${ }^{12}$ Nevertheless, as the company continued to use convict workers until I930, albeit in smaller numbers (see Table 2), the juridical or ethical motives were not the only explanation for discharging convict workers. The introduction of machinery was equally crucial. The installation of a huge steam-generated water pump in the early I890s was a decisive moment for the industrialization of the Miike Mine. Clearing the underground water no longer required human labour, making the convict workers partially dispensable. ${ }^{\mathrm{I}}$ At the same time, the convict workers were still needed for hewing and hauling, which continued to rely on manual labour. However, they were not considered ideal by the company. This was the occasion when Mitsui turned fully to non-convict workers, first female then male miners.

As shown in Table 2, the number of convict workers drastically decreased from i 898 to 1902, largely due to the Prison Law. In stark contrast, while there were only 75 female workers in 1899 when the law was enforced, the number skyrocketed to 572 in the following year. Those women workers, who likely came from peasant households nearby, were paid less than their

I I. This and the other printed and unprinted documents authored by Mitsui Kōzan used in this article can be consulted at the Mitsui Bunko [Mitsui Archives], Tokyo.

I 2. Naoki Tanaka, Kindai Nihon Tankō Rōdōshi Kenkyū [Labour History of Japanese Coalmining] (Tokyo, I984), p. 269.

I 3. Hashimoto, "Mitsui Kōzan to Shūjinnōdō", p. 4I6. 
male counterparts, and in this respect they shared features with the convict workers. When in I90I the remaining convict workers at the Katsudachi pit were relocated to the Miyanohara pit, the company soon lifted a ban on using female workers in the Katsudachi pit. ${ }^{14}$ These female workers were obviously brought into the production process to compensate for the dwindling number of convict workers upon the passage of the reform law.

Female workers represented more than the mere replacement of the convict workers, however. Along with the water pump, the mechanical winch was introduced during the mid-I 890 s. It automated the transportation of coal from the main shaft inside the pit to the surface. As this task had presumably been handled by the convict workers before, the machine replaced some of their labours. On the other hand, the installation further intensified the use of manual labour in the underground pit to keep pace with the machine. In this way, the mechanization of transport created more jobs for the coal haulers, who transported coal from the coalface to the main shaft manually. As this work required less skill and probably less strength compared with the work of the coal hewer, Mitsui Kōzan turned to female workers for the hauling jobs. By assigning these jobs to women, the company was able to optimize the production process. ${ }^{15}$

Furthermore, the company had another motive for incorporating female miners. To increase production and the return on the investment in new machinery, the company needed to hire more male hewers. To secure a stable workforce of male miners, the company strategically hired their wives as haulers. Especially in "room and pillar" mining - still the predominant method around 1900 - pairs of married couples were assigned to respective "rooms", where a husband worked as a hewer and his wife as a hauler. Together they formed a "family-style employment structure based upon a dual-income household" ${ }^{16}$ The increase in the number of female workers in 1900 marked Mitsui Kōzan's initial move toward this structural change - that is, the expansion of its workforce by discharging convict workers.

Table 2 shows that, while there were around I,457 convict pit workers (hewers and haulers) at the peak of their employment in I 896, their number decreased quickly in the following years. In contrast, although the number of male workers, surface and underground combined, at Miike decreased

I4. Mitsui Kōzan, Shūto Saitan no Yurai [The Origin of Convict Miners] (Tokyo, n.d. [1943]), p. 4. The Katsudachi pit is also colloquially called the Kaddachi or Katsudate pit. The Miyanohara pit was referred to as the Miyahara pit in the past.

I s. Yutaka Nishinarita, "Sekitan Kōgyō no Gijutsu Kakushin to Joshi Rōdō" [Technological Development and Female Labour in the Coal Industry], in Nakamura Masanori (ed.), Gïutsu Kakushin to Joshi Rōdō [Technological Development and Female Labour] (Tokyo, I985), pp. 7I-IO5, 75 .

16. Ibid. All translations from Japanese are ours. 
from 5,077 in 1899 to 4,520 in 1900 , perhaps because of the Prison Law, thereafter it increased again to 5,205 in I90I. Notably, the number of non-convict pit workers reached 2,000 by 1908 and continued to increase in the following years. Within a few years of the Prison Law, the non-convict miners, male and female together, exceeded the number of convict miners at the peak of I 896. This trend suggests that, even without the Prison Law, the supply of convict workers alone would not have been enough to increase production at the mine.

For example, had Mitsui Kōzan continued to use convict workers in its newly opened Manda pit in 1903, one of the largest pits at the Miike Mine, the company would have needed to bring more prisoners from elsewhere, which would have cost more since it would have entailed, for example, constructing new corresponding facilities. Therefore, with or without the Prison Law, it is highly probable that the reliance on prisoners became an obstacle to the prospective growth of the mine. Although the wages of the prisoners were lower than those of the non-convict miners, the need for enhanced capital accumulation rendered convict workers "unattractive" in the long run: there were extra costs attached to them and they were considered less productive than non-convict labourers. Sooner or later, the company would have required non-convict workers.

The simultaneous use of convict and non-convict miners must have caused problems too. Their presence in a pit perhaps made it more difficult for the company to secure a stable labour force, for it is not hard to imagine that toiling side by side with prisoners in the same pit was not appealing to others. This explains why, after I90I, all convict workers were relocated to the Miyanohara pit, which was destined to be closed. ${ }^{17}$ As the company had calculated that the Miyaura pit and the Manda pit were more productive, non-convict workers were assigned to these pits. In a way, the Prison Law conveniently shrank the pool of convict workers and made it easier for the company to insulate them from the others. Doing so enabled Mitsui Kōzan to recruit more non-convict hewers, while using the labour of the prisoners at the waning pit until the end (the Miyanohara pit closed in 193 I).

At the same time, there is no doubt that Mitsui Kōzan had gained tremendous profits from the forced labour of the convict workers. By the early i9 Ios, the Miike Mine became the cashbox for the company. It yielded approximately 2,000,000 tons of coal by I9I 2, the largest volume of any of Japan's mines. This abundant production and capital accumulation at the Miike Mine greatly helped the subsequent operation of their mines in Chikuho ${ }^{18}{ }^{8}$ Thanks to the convict workers in Miike, the company became

I7. Ibid., p. 22.

I8. See Hideki Hatakeyama, Kindai Nihon no Kyodai Keiei: Mitsubishi Zaibatsu no Jirei Kenkyū [Giant Enterprise in Modern Japan: A Case Study of Mitsubishi] (Tokyo, 2000), p. 7. 
wealthy enough to hire non-convict workers and managed to increase production at its mines. Furthermore, the convict wages functioned as a benchmark for the company, leading it to lower the cap on wages for the subsequent non-convict Japanese miners. ${ }^{19}$ In a way, the convict workers defined the labour conditions of those who followed.

\section{WAGES}

Having discharged the majority of the convict workers, since the dawn of the twentieth century Mitsui Kōzan began hiring former peasants from the vicinity of the Miike Mine. "With regard to the employment of miners", wrote an office manager of the company, "one of the difficult parts is their wage." ${ }^{20}$ The manager reasoned that the company should not hire "experienced" persons since they "try to leave the mine". Instead, it had to look for "unsophisticated" peasants, for they tended to stay longer and "the company does not have to raise the wage [to attract them]". ${ }^{21}$ From these passages, we can surmise how important it was for the company to secure a stable workforce and how the wage was the crucial factor for both the miners and the company.

Interestingly, the officer wrote in the same report that, "as persons often come from Chikuho to steal miners [from the Miike Mine], the company should always tighten security". ${ }^{22}$ This remark suggests that the mines in Chikuhō (at least those not pertaining to Mitsui Kōzan) had more difficulty in retaining enough miners. As wages were the crucial factor for both the employment and retention of miners, in this section we will briefly look at the wages of miners at the different mines in the Chikuhō region in the early I9Ios. As will be shown later, the varying wage scales across the companies reflected their respective employment strategies toward Korean miners later on.

Table 3 presents the average daily wages for male miners at Chikuhō mines in I9I 2, two years after the annexation of the Korean peninsula. The table makes clear that wages fluctuated from one company to another. The highest wages were paid in the three mines of Mitsui Kōzan, averaging 0.78 yen. Mitsubishi Kōgyō and Asō Shōten (or their predecessors) paid the lowest wages, averaging 0.68 yen and $0.6 \mathrm{I}$ yen respectively. ${ }^{23}$

19. Toyoo Shindō, Akai Botayama no Hi: Chikuhō Miike no Hitobito [Red Fires of Coal-slag Heap: People in Chikuhō and Miike] (Tokyo, 1985), p. I 54.

20. Mitsui Kōzan, Mïke Kōgyōsho Enkaku-shi: Rōmu, III [History of the Mitsui Mine: Labour Management, III] (Tokyo, I 943), p. 637.

21. Ibid., p. 638 .

22. Ibid.

23. In I9I 2 the Mitsubishi mines were administered by the Mitsubishi Co., and the Asō mines were administered by Taichi Asō, a founder of Asō Shōten. Both Mitsubishi Kōgyō and Asō Shōten were formally established in I9I 8. 
Table 3. Wages for male pit workers paid at different Chikubō mines in I9I2.

\begin{tabular}{|c|c|c|c|c|c|c|c|}
\hline Company* & Mine & Miners & $\begin{array}{l}\text { Wages } \\
\text { (yen) }\end{array}$ & Company & Mine & Miners & $\begin{array}{l}\text { Wages } \\
\text { (yen) }\end{array}$ \\
\hline \multirow[t]{3}{*}{ Mitsui } & Tagawa & 1,402 & 0.845 & \multirow[t]{3}{*}{ Meiji } & Meijił & 1,194 & 0.830 \\
\hline & Yamano & 844 & 0.695 & & Hōkoku & 857 & 0.778 \\
\hline & Hondō & 861 & 0.810 & & Akaike & 279 & 0.700 \\
\hline \multirow[t]{5}{*}{ Mitsubishi } & Shinnyū & 918 & 0.679 & \multirow[t]{2}{*}{$\begin{array}{l}\text { State- } \\
\quad \text { owned }\end{array}$} & $\begin{array}{l}\text { Shinbaru } \\
\text { Kaigun\# }\end{array}$ & 569 & 0.779 \\
\hline & Namazuta & 1,370 & 0.640 & & Futase & 1,425 & 0.742 \\
\hline & Hōjō & 520 & 0.711 & Iwasaki & Iwasaki & 326 & 0.685 \\
\hline & Kamiyamada & 441 & 0.660 & Arate & Arate & 296 & 0.695 \\
\hline & Kanada & 530 & 0.687 & Itō & Nakazuru & 355 & 0.735 \\
\hline \multirow[t]{2}{*}{ Asō } & Mameda & 346 & 0.597 & Miyoshi & Miyoshi & 277 & 0.714 \\
\hline & Yoshio & 652 & 0.620 & & Takamatsu & 174 & 0.613 \\
\hline \multirow[t]{2}{*}{ Kaijima } & Ōnoura & 1,647 & 0.780 & Hori & Gotoku & 248 & 0.748 \\
\hline & Ōtsuji & 497 & 0.700 & Koyanose & Koyanose & 407 & 0.793 \\
\hline \multirow[t]{2}{*}{ Furukawa } & Furukawat & 536 & 0.760 & \multirow[t]{2}{*}{ Kurauchi } & Mineji & 1,205 & 0.750 \\
\hline & Shimoyamada & 557 & 0.730 & & Ōtō & 401 & 0.880 \\
\hline Sumitomo & Tadakuma & 815 & 0.740 & Nakano & Aida & 157 & 0.550 \\
\hline
\end{tabular}

* Regarding the ownership of each mine, we relied on the information for I9I 3.

Hence, some mines might have been owned by different companies in I9I 2.

$\dagger$ The figures are for three Furukawa-owned mines: Shiogashira, Shakanō, and

Katsuno.

$\ddagger$ The figures include the numbers of and wages for pit timberers and haulers.

\# The mine was located in the present-day Kasuya district, west of the Chikuhō region.

Source: Chikuhō Sekitan Kōgyō-shi Nenpyō Hensan Iinkai [Committee for the Compilation of a Historical Chronology of the Chikuhō Coal Industry] (ed.), Chikuhō Sekitan Kōgyō-shi Nenpyō [Historical Chronology of the Chikuhō Coal Industry] (Fukuoka, I973), p. 255.

As it is not likely that the higher wages paid by Mitsui Kōzan were a consequence of longer working hours, they do suggest that there were differences in productivity between Mitsui Kōzan and other companies. Whatever the reasons for the varying productivity, our contention is that the corresponding higher wages at the Mitsui Kōzan mines in Chikuhō would have been impossible without the profits at the Miike Mine. Without the state-funded start of production and the labour of convict workers at Miike, Mitsui Kōzan would have been unable even to purchase those mines in Chikuhō in the first place. Thanks to the preconditions at and the continual prosperity of the Miike Mine, the mines operated by Mitsui Kōzan in Chikuhō had access to enough capital possibly to invest in better machinery and to spend on the wages of their workers. ${ }^{24}$ Accordingly, as we will

24. The wages at the Miike Mine were in fact lower than some of those at Mitsubishi's mines in Chikuhō. This might be due to the geographical location. As the only mine in the region, the 
demonstrate below, the company was able constantly to increase the number of Japanese miners and production throughout the rest of the igros.

Judging from the wages paid in I9I 2 at the Mitsubishi Kōgyō and Asō Shōten mines in Chikuhō, these were not as economically prosperous as the Mitsui Kōzan mines. This might have been due to the geological conditions of the mines, the scarcity of capital, or all of those factors combined. Without the preconditions of Miike and subsequent capital accumulation, both companies inevitably had to build their respective production lines from what they had available, for which Korean miners became an indispensable workforce.

\section{UNEVEN DISTRIBUTION OF KOREAN MINERS}

Table 4 shows the distribution of Korean miners across the larger mines in Miike and Chikuhō in the late ig2os. As becomes clear from the table, Mitsubishi Kōgyō and Asō Shōten relied on heavily colonial labour, while the Miike Mine employed only 7 Koreans, a negligible number considering that there were over I I,, 00 workers at this mine (surface and underground combined). Although the table does not include the figures for the Mitsui Kōzan mines in Chikuhō (Tagawa and Yamano), it is likely that the percentages of Koreans there were equally negligible.

The virtual absence of Korean miners at the Mitsui Kōzan mines was the consequence of the company's guiding precept, Seibyo-Shugi. In an overview of its fifty-year history, Mitsui Kōzan itself defined the ideal labourer - Seibyo (elite troop) - as somebody with a "trustworthy personality, sound thought, and strong body". ${ }^{25}$ Korean miners apparently did not fit this criterion. According to the company's own historical overview, Mitsui Kōzan first recruited 102 Korean miners in I9I7 at its Kawakami Mine in South Sakhalin, then part of Japan's colonial empire along with the Korean peninsula (see Figure I). This resulted in a series of conflicts, including a massive brawl with Japanese miners. Adding to the worries of the company were the language barrier and the apparently high illiteracy rate among Koreans, which in its view hampered the Koreans' "working efficiency". Following these experiences and the principle of Seibyō-Shugi, Mitsui Kōzan thus decided not to employ colonial workers

Miike Mine monopolized the demand for labour and might not have had to compete with other mines by raising wages.

25. Mitsui Kōzan, Gojūnen-shi Kō, Iohen, Rōmu [Draft of so-Year History of Mitsui Kōzan, X, Labour Management] (Tokyo, I943), p. I47. Since this document was prepared in I943, it is not certain whether the term Seibyo-Shugi had already been used in the late I9Ios. Although it might have been retrospectively defined, we use the term to characterize Mitsui's discriminative management policy also in the r 910 and 1920 s. 
Table 4. Korean miners in some major mines in Miike and Chikubo, March 1928.

\begin{tabular}{|c|c|c|c|c|}
\hline \multirow[b]{2}{*}{ Company } & \multirow[b]{2}{*}{ Mine } & \multirow{2}{*}{$\frac{\text { All miners }}{\text { Total }}$} & \multicolumn{2}{|c|}{ Korean miners } \\
\hline & & & Underground & Surface \\
\hline \multirow{4}{*}{$\begin{array}{l}\text { Miike } \\
\text { Mitsui } \\
\text { Chikubo } \\
\text { Mitsui }\end{array}$} & & & & \\
\hline & Miike & $11,136^{*}$ & 5 & 2 \\
\hline & Tagawa & $7,156^{*}$ & [n.a.] & [n.a.] \\
\hline & Yamano & $3,650 *$ & [n.a.] & [n.a.] \\
\hline \multirow[t]{4}{*}{ Mitsubishi } & Kamiyamada & 2,657 & 218 & 121 \\
\hline & Namazuta & 4,543 & 1,494 & 244 \\
\hline & Shinnyū & 2,846 & 873 & 71 \\
\hline & Hōjōo & 2,746 & 392 & 21 \\
\hline \multirow[t]{3}{*}{ Asō } & Yoshio & 2,995 & 48 & 90 \\
\hline & Yoshikuma & 1,614 & 96 & [n.a.] \\
\hline & Tsunawake & 983 & 110 & 16 \\
\hline Kaijima & Ōnoura & 9,512 & 58 & 154 \\
\hline Nakajima & Iizuka & 5,801 & 1,687 & 81 \\
\hline
\end{tabular}

* These figures refer to the number of workers at the respective mines for the whole of I928, while all other figures indicate the numbers during March of the same year. Sources: Fukuoka Chihō Shokugyō Shōkai Jimukyoku [Fukuoka Employment Bureau], Kanai Zaijū Chōsenjin Rōdo Jijo [Working Conditions of Korean Workers in Fukuoka] (Fukuoka, I930), pp. 83-89, available at the Digital Library from the Meiji Era, http://kindai.ndl.go.jp/, last accessed is June 20I 5; Yutaka Nishinarita, "Sekitan Kōgyō no Gijutsu Kakushin to Joshi Rōdō" [Technological Development and Female Labour in the Coal Industry], in Nakamura Masanori (ed.), Gijutsu Kakushin to Joshi Rōdo [Technological Development and Female Labour] (Tokyo, I985), pp. 7I-Io5; Mitsui Kōzan, Gojūnen-shi Kō.

any more (a policy that, in any case, was altered in the late I930s when the Japanese war effort intensified). ${ }^{26}$

Obviously, Seibyo-Shugi was a racially ethnically discriminative precept, deeming all Korean miners "unproductive". Leaving its discriminatory aspect aside, however, what made Seibyo-Shugi possible in the first place? What deserves attention here are both the preconditions and the effects of this policy. Mitsui Kōzan fully understood that the Korean workers could have become an immediately available and cheap workforce, as their recruitment fee was also lower. Moreover, in the company's view, they adapted more easily to bad working conditions compared with Japanese miners. ${ }^{27}$ Still, the company considered relying on Japanese miners, "unsophisticated peasants", or skilled coal hewers a better employment 
strategy, although this was more expensive. It is clear that this policy of ethnic homogenization of the workforce and its benefits were made possible by the company's preconditions at Miike and resulting capital accumulation, enough to recruit "elite troops".

In order to measure the capital accumulation and corresponding productivity, the Mitsui Yamano Mine and some Mitsubishi mines in Chikuhō will provide a useful contrast here. As already indicated in Table 3, the Yamano Mine was the least productive among the Mitsui Kōzan mines in Chikuhō in I9I 2. Still, Table 5 shows that the Yamano Mine managed to increase its coal output from 373,629 tons in 1916 to 453,029 tons in 1920 in response to the swelling demand for coal due to World War I. During the same period, as evident from the same table, the output from the Namazuta Mine, one of the most mechanized Mitsubishi Kōgyō mines in the late I9Ios, increased only from 449,33 I tons to 470,504 tons. Therefore, despite the low productivity earlier in the decade, the Yamano Mine was able to catch up quickly with one of Mitsubishi's most industrialized mines by 1920 .

As the Yamano Mine then still heavily relied on manual labour, this growth in production must have involved securing more underground pit workers. ${ }^{28}$ Wage thereby becomes the indicator of how successful their recruitment was. As Table 5 shows, while the price of rice - a metonym for the miners' standard of living - was rising, the Yamano Mine increased wages for their miners during the period: from 0.79 yen in I9I 6 to 2.53 yen in 1920, consistently higher than the average wage in Chikuhō. Accordingly, the total number of workers also increased, from 3,4 IO in I917, to 4,423 in 1919 and 4,750 in $1920 .{ }^{29}$ This makes a good contrast with the Mitsubishi Kōgyō Shinnyū Mine. Although by the mid-ı́ros the Shinnyū Mine offered the highest wages among the Mitsubishi mines in Chikuhō, the average wage remained lower than that paid by the Yamano Mine. Moreover, while the difference in wages between the two mines was not large in I9I6, it became more pronounced in the period leading up to I920. These comparisons seem to indicate that the expansion of production as well as the recruitment and retention of an ethnically homogeneous labour force at the Mitsui Kōzan mines was perhaps realized more smoothly through higher wages.

Although we do not have much data on the wages of workers at Mitsubishi Kōgyō, this comparison with Mitsui Kōzan at least allows a glimpse of their productivity and employment conditions. Judging from their wages (Table 5), we can surmise that the company must have been less

28. The Tagawa Mine (Mitsui Kōzan) and the Namazuta Mine (Mitsubishi Kōgyō) had already introduced the coal cutter in I917. See Yoshihiro Ogino, Chikuhō Tankō Rōshi Kankeishi [History of Labour Relations in Chikuhō Coalmines] (Tokyo, I993), p. I 44.

29. Mitsui Kōzan, Gojūnen-shi Kō. 







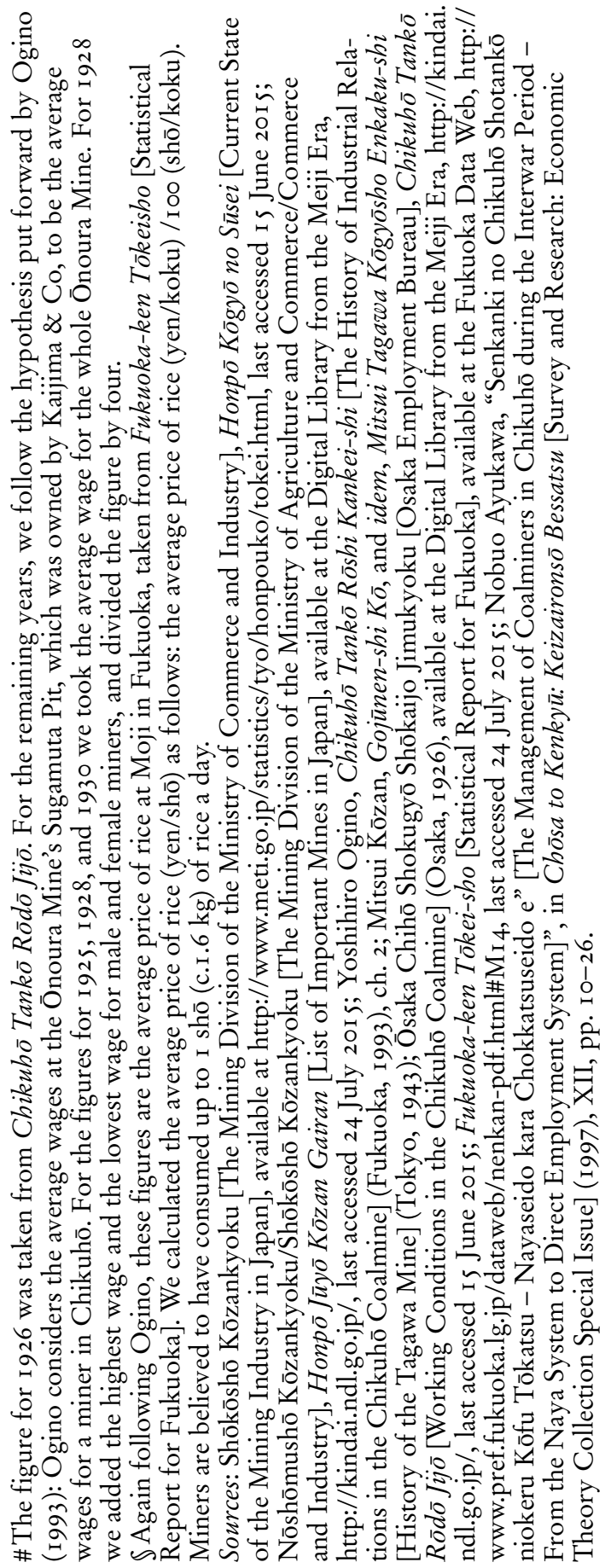


successful in securing labour throughout the I9Ios, especially compared with Mitsui Kōzan. The labour shortage must have been a serious issue, especially when demand for coal began to soar in I9I6. It is thus not surprising that the company began recruiting Korean workers on a large scale precisely during this period.

At the end of June I9I7 the Mitsubishi Kōgyō Kamiyamada Mine recruited just over 200 Korean miners to supplement the existing workforce. According to a government survey at the time, there were 1,825 miners, underground and surface included, working at the mine in $1917 . .^{\circ}$ In previous years, the mine had apparently been running at an economic loss, which explains why the average wage for a pit worker was one of the lowest among the Mitsubishi mines. ${ }^{\text {I }}$ In fact, while the value of total output from the Kamiyamada Mine was increasing, due to rising coal prices, the actual output of coal declined, from 184,626 tons in I916 to I65, I 85 tons in 1917 (see Table 5). This indicates that the mine had insufficient capital to offer higher wages, and accordingly that there were not enough miners to sustain production. The Korean workers seem to have come in the midst of this crisis and, notably, the mine's output began to recover in the following years, rising from I69,689 tons in I9I 8 to 2 I I,650 tons in 1920. Although the deployment of Koreans was probably not the only reason, their labour, however transitory, must have served in the recovery, as a "colonial gift".

In fact, in September 1917, the Kamiyamada Mine was indicted by a court for imposing a sanction on twenty-five "abductors", who had kidnapped [mostly] Korean miners from them. ${ }^{32}$ The incident indirectly reveals how desperately the mine needed these migrant workers and how jealously the company tried to retain them. Subsequently, at the beginning of the following year, Mitsubishi Kōgyō applied for permission to recruit more Korean workers for the Namazuta Mine and Shinnyu Mine from the South Gyeongsang province as well as from the South Chungcheong province in Korea (see Figure I). The Korean workers were recruited to keep the mine's production in pace with the increasing demand for coal - quite similar to how convict workers had been mobilized to assist the mechanization process at the Miike Mine a few decades earlier. Table s further shows that, even after 1920, wages at the Mitsubishi Kōgyō mines, especially those like the Shinnyu Mine which depended heavily on Korean workers, remained low. In other words, Mitsubishi Kōgyō must have been less successful than Mitsui Kōzan in securing its workforce during this period.

30. See Chikuhō Sekitan Kōgyō-shi Nenpyō Hensan Iinkai, Chikubō sekitan kōgyō-shi nenpyō, p. 28I, and Nōshōmu Shō Kōzan Kyoku [Mining Division of the Ministry of Agriculture and Commerce], Honpō Jūyō Kōzan Yōran [List of Important Mines in Japan] (Tokyo, 191 8), p. 907. 3. Hatakeyama, Kindai Nihon no Kyodai Keiei, p. 23.

32. Chikuhō Sekitan Kōgyō-shi Nenpyō Hensan Iinkai, Chikubō Sekitan Kōgyō-shi Nenpyō, p. 283 . 
As far as Asō Shōten is concerned, we do not have enough documentation to demonstrate when and under what circumstances Asō Shōten began recruiting Korean labourers to their respective mines. ${ }^{33}$ Although the company was historically notorious for uncompromisingly low wages - it was often referred to as the "despotic mine" (assei no yama) - Table 5 surprisingly shows that the wages in its Yoshio Mine and Tsunawake Mine were not drastically lower than those at the mines owned by Mitsui Kōzan in the late I9ros. ${ }^{34}$ However, neither coal output nor the corresponding value of the coal produced at the two mines increased as much as they did at Mitsui or Mitsubishi. Moreover, as indicated in Table 5, average wages at the Asō mines dropped below the average at Chikuhō, almost the lowest among the three companies by the late I920s, at which point Asō Shōten was already relying on Korean miners. It is highly probable that the company, much more than Mitsubishi Kōgyō, suffered from labour shortages in those years, and that the availability of Korean labour was a matter of life and death for the survival of their mines.

In sum, the colonial surplus population remained a vital source of labour throughout the I920s at the lower-wage mines of Asō Shōten and the Mitsubishi Kōgyō. The existing scholarship problematizes the way in which these companies took advantage of the "ethnic difference" and exploited Korean miners as a cheap workforce. Yet, as Donald Smith writes, it is hard to track down exact figures for the wages of Korean miners during the interwar period, largely because of the scarcity of archival sources. ${ }^{35}$ What can be said, based on the information available, is that the labour of the colonial miners enabled Asō Shōten and Mitsubishi Kōgyō to manage their mines without drastically increasing wages and helped these companies to keep wages down even for the Japanese miners. In that sense, the Korean immigrant miners played a role similar to that of the convict workers at Mitsui Kōzan in the late I89os.

\section{CONCLUSION}

As the annexation of Korea in I910 further reconfigured the economic structure of the then agrarian countryside of the Korean peninsula, many impoverished peasants lost their lands. Those peasants became a colonial surplus population in need of jobs to sustain their lives. Just as, a few decades earlier, the legal system had provided Mitsui Kōzan with an allotment of convict workers, colonialism in effect produced a vast pool of

33. According to Yasuto Takeuchi, several sources indicate that the company first used Korean miners in the late ı 9 Ios; Takeuchi, Chōsa: Chōsenjin Kyōsei Rōdō, I, p. I 8 I.

34. Eidai Hayashi, Chikubō Gunkanjima: Chōsenjin Kyōsei Renkō, Sonogo [Chikuhō and Gunkanjima: The Forced Recruitment of Koreans, and After] (Fukuoka, 201 I), p. 53.

35. Smith, "Ethnicity, Class and Gender in the Mines", p. 69. 
immediately available labour with a low recruitment fee. ${ }^{36}$ For companies such as Mitsubishi Kōgyō and Asō Shōten, the Korean surplus population was a colonial gift they could not resist.

In our view, the uneven distribution of the Korean workforce in Chikuhō during the colonial period was related to the "monopolization" of convict workers at Miike a few decades earlier. The unevenness reveals the ways in which companies capitalized on respective preconditions and their effect on employment strategies. Such an analysis could potentially be expanded to include other companies or coalfields in Japan itself, such as Ishikari (Hokkaidō) and Nishisonogi (Nagasaki), but also in Japan's former colonies (for example, South Sakhalin or Manchuria).

From the late ig2os the companies initiated, under the banner of a "rationalization policy" (gōrika seisaku), a reduction of the workforce and a mechanization of the mining process by introducing, for example, the coal cutter and the conveyor belt. The chronic economic recession of this period urged the companies to carry out this rationalization process. While replacing the labour of underground workers with machinery, in 1930 Mitsui Kōzan decided to impose a "ban" on the use of female pit miners, along with the remaining convict workers. Senior workers, long-time employees, and high-wage earners were also fired. Instead, the company kept only the core workforce (chüken rōdosha) - "robust healthy [male] workers in their 20 s and 305 " - and thus further solidified the principle of Seibyo-Shugi by homogenizing the workers in relation to age and gender. ${ }^{37}$

At the Mitsubishi Kōgyō mines, too, many Korean workers were discharged, beginning in the late 1920 , due to the recession..$^{38}$ Although we cannot investigate here in depth what was at work in these layoffs, through this policy Mitsubishi Kōgyō established its own version of Seibyō-Shugi; it proved how disposable immigrant labour was in the face of socio-economic troubles. Although their wages were most likely the lowest, the company, by discharging them, could save the jobs for Japanese miners - the "elite troops" who were becoming militant during the recession.

Thus, each company had - though in different ways according to the moment, the circumstances, and its own possibilities - ways to secure a reserve of a particular type of workforce; defining them by criminality, gender, ethnicity, nationality, or age and, depending on the amount of their capital accumulation, these companies sought to construct alterity through those distinctions to establish considerable wage differentials. Although the economic benefits of this constellation were important, over time the

36. For further information on the recruitment of Korean workers, see Kawashima, The Proletarian Gamble, pp. 28-43.

37. Mitsui Bunko, Mitsui Jigyō-shi [History of the Mitsui Enterprise], III, pt. 2 (Tokyo, I994), p. 95 .

38. Smith, "Ethnicity, Class and Gender in the Mines", p. i 19. 
companies tended to dispose of these "non-elite" groups of workers and to replace them with a more homogenized workforce (male, young, Japanese) - sometimes accompanied by a rhetoric of miners as vanguard workers. Thus, both the evolving logic of capital accumulation and the circumstances (infrastructure, economic situation, state policy, workers' resistance) saw companies making, at given moments, different valuations and subsequent adjustments in relation to the workforce composition. 